\title{
The role of environmental perceptions in migration decision-making: evidence from both migrants and non- migrants in five developing countries
}

\author{
Vally Koubi ${ }^{1,2} \cdot$ Gabriele Spilker $^{3} \cdot$ Lena Schaffer $^{4}$ • \\ Tobias Böhmelt ${ }^{1,5,6}$
}

\begin{abstract}
Research has demonstrated that, in a variety of settings, environmental factors influence migration. Yet much of the existing work examines objective indicators of environmental conditions as opposed to the environmental perceptions of potential migrants. This paper examines migration decision-making and individual perceptions of different types of environmental change (sudden vs. gradual environmental events) with a focus on five developing countries: Vietnam, Cambodia, Uganda, Nicaragua, and Peru. The survey data include both migrants and non-migrants, with the results suggesting that individual perceptions of long-term (gradual) environmental events, such as droughts, lower the likelihood of internal migration. However, sudden-onset events, such as floods, increase movement.
\end{abstract}

Vally Koubi

koubi@ir.gess.ethz.ch

Gabriele Spilker

gabriele.spilker@sbg.ac.at

Lena Schaffer

lena.schaffer@uni-konstanz.de

Tobias Böhmelt

tbohmelt@essex.ac.uk

1 Center for Comparative and International Studies (CIS), ETH Zurich, IFW C 43.2, Haldeneggsteig 4, 8092 Zurich, Switzerland

2 Department of Economics, University of Bern, Bern, Switzerland

3 Department of Political Science and Sociology, University of Salzburg, Rudolfskai 42, 5020 Salzburg, Austria

4 Department of Politics and Public Administration, University of Konstanz, Box 86, Universitätsstr. 10, 78457 Konstanz, Germany

5 Department of Government, University of Essex, Winenhoe Park, Colchester CO4 3SQ, UK

6 Institute for Environmental Decisions (IED), ETH Zurich, Zurich, Switzerland 
These findings substantially improve our understanding of perceptions as related to internal migration and also suggest that a more differentiated perspective is needed on environmental migration as a form of adaptation.

Keywords Environmental change - Individual perceptions · Migration - Sudden events · Gradual events

\section{Introduction}

The debate on the consequences of climate change increasingly focuses on the relationship between environmental change and human migration. While the empirical evidence for the link between climate-related environmental events and migration remains inconclusive (Black et al. 2011c: 435), it is in fact the case that policymakers, public institutions, and scholars often argue that climate change is expected to lead to migration due to extreme sudden weather events, such as stronger and more recurrent storms or floods as well as long-term, gradual events, such as droughts and rising sea levels (see also Foresight Migration Project 2011; Jäger et al. 2009; Laczko and Aghazarm 2009). For instance, according to the recent Intergovernmental Panel on Climate Change (IPCC) (2014: 16) report, "[c]limate change is projected to increase displacement of people (medium evidence, high agreement)."1 However-for the most part-estimates predicting environmental migration ${ }^{2}$ to occur at a larger scale in the future have been widely criticized. The critique primarily stems from the overestimation of the number of environmental migrants due to two reasons. First, figures are usually based on the people exposed to increasing environmental risks, and not on the people actually expected to migrate. Second, these studies do not account for different levels of vulnerability to environmental change and potential adaptation strategies (Adger et al. 2015; Hunter et al. 2015; McLeman 2014; Gemenne 2011; Black et al. 2011a, c; Kniveton et al. 2008).

Still, there is anecdotal evidence, suggesting that weather variability may lead to migration flows. For example, in the 1930s, an estimated two-and-a-half million North Americans are said to have left the Great Plains because of droughts and dust storms (Reuveny 2007; see also McLeman 2006, 2014); and in 2005, Hurricane Katrina resulted in one-and-a-half million people being displaced temporarily and about 500,000 permanently (McLeman 2014; Fussell et al. 2010). Unfortunately, such case-specific evidence does not allow for general conclusions with respect to whether and how environmental change actually affects migration. In addition, the environment-migration relationship may well be conditional on various individual,

\footnotetext{
1 Moreover, "displacement risk increases when populations that lack the resources for planned migration experience higher exposure to extreme weather events, such as floods and droughts...Changes in migration patterns can be responses to both extreme weather events and longer term climate variability and change, and migration can also be an effective adaptation strategy" (IPCC 2014: 73).

2 We use the term "environmental migration" when referring to persons who are displaced primarily for environmental reasons (see Dun and Gemenne (2008) for a thorough discussion of the definition of "environmental migration").
} 
socioeconomic and political factors, which require a more generalizable empirical analysis than case-specific studies can provide (e.g., Adger et al. 2015; Hunter et al. 2015; McLeman 2014; Black, et al. 2011a, c).

That said, there exists a large body of literature studying the impacts of the environment on internal and international migration using macro-level (e.g., Beine and Parsons 2015; Robalino et al. 2015; Marchiori et al. 2012; Black et al. 2011c; Feng et al. 2010; Saldaña-Zorrilla and Sandberg 2009; Reuveny and Moore 2009; Myers et al. 2008) or micro-level (e.g., Kelley et al. 2015; Bohra-Mishraa et al. 2014; Mueller et al. 2014; Penning-Rowsell et al. 2013; Gray and Mueller 2012a, b; Dillon et al. 2011; Doevenspeck 2011; Massey et al. 2010; Gray 2009, 2011; Mortreux and Barnett 2009; Halliday 2006; Paul 2005; Henry et al. 2004) data and a diverse range of approaches, including quantitative methods, qualitative research, or both methods. ${ }^{3}$ While these works offer intriguing insights into the complex relationship between environmental change and migration, their findings remain, as indicated above, inconclusive (Adger et al. 2015; Hunter et al. 2015; IPCC 2014; Obokata et al. 2014; Gray and Bilsborrow 2013; Black et al. 2011a, c; Raleigh et al. 2008). This empirical ambiguity may, on the one hand, stem from the lack of theoretical work and data, which induces that our knowledge on which individuals decide to migrate and which decide to stay-and why-remains limited. On the other hand, most studies focus only on one aspect of environmental change, such as flood, rainfall/temperature changes, or drought, and do not simultaneously examine the effects of different types of environmental change on migration in order to infer their unbiased individual effect on migration likelihood. In addition, previous research has not sufficiently addressed why environmental change causes migration in some regions or countries, but not in others (see also Adger et al. 2015; Hunter et al. 2015, McLeman 2014, and Black et al. 2011a, c).

In order to address these issues, our first contribution to the literature comes from developing a theoretical argument that links individual perceptions of different types of environmental change to individuals' decisions to migrate or stay. ${ }^{4}$ To this end, and as elaborated thoroughly in the theoretical section below, we choose the term perceptions to express that we capture not only individuals' exposure to environmental change and, eventually, their willingness to migrate, but also their capability and opportunity to actually do so (see also Most and Starr 1989). Second, we focus on two types of environmental change that may affect migration: sudden and shortterm vs. slow-onset and long-term environmental events. As Black et al. (2011c: 437) emphasize such a distinction "is useful in terms of both aiding understanding [environmental migration], as well as identifying key policy implications."

\footnotetext{
${ }^{3}$ For a more comprehensive and detailed review of the existing literature, see Adger et al. (2015), Hunter et al. (2015), McLeman (2014), Piguet (2010), or the Foresight Project (2011).

${ }^{4}$ We study voluntary migration, which occurs when environmental events lead to temporary disruption of livelihoods or to deterioration of environmental conditions, as opposed to forced migration, which occurs when environmental events threaten the physical safety of populations or lead to unfeasible livelihoods (see Renaud et al. 2011). Moreover, we focus on internal migration as there is strong consensus in the literature that most migration flows associated with environmental factors are of an internal nature (Hunter et al. 2015: 3; Foresight Project 2011; Adamo and Izazola 2010; Raleigh et al. 2008).
} 
Empirically, the corresponding arguments are analyzed with newly collected survey data, which comprise both individuals who migrated and individuals who decided to stay in five countries: Vietnam, Cambodia, Uganda, Nicaragua, and Peru. As indicated, a key strength of these new data is that we integrate individual environmental perceptions with other migration-relevant determinants at the individual and household levels to provide a more complete picture of the decision to migrate or stay (Adger et al. 2015; Hunter et al. 2015; Black et al. 2011c; Bardsley and Hugo 2010; Hunter 2005; Stark and Bloom 1985). In addition, the focus on environmental perceptions fills an empirical gap that was recently identified by Hunter et al. (2015: 13). We find that the effects of individual perceptions of and attitudes toward environmental change strongly depend on the nature of the environmental event: While long-term, gradual environmental events, such as drought or salinity, lower the likelihood of migration, sudden-onset environmental events, such as storms or floods, usually tend to increase it.

\section{What determines individual environmental migration decision?}

While earlier studies on environmental migration draw on neo-Malthusian arguments, which claim that there is a direct and unidirectional impact of environmental change on migration, recent research is based on a more complex pattern of causality in which environmental, economic, political, social, and demographic factors are interrelated. Understanding these interrelationships facilitates disentangling the role that environmental factors play in population movements (Adger et al. 2015; Hunter et al. 2015; McLeman 2014; Black et al. 2011a, c; Piguet et al. 2011).

However, thus far, we lack a coherent theory of migration and face instead a fragmented set of approaches that are often segmented by disciplinary academic boundaries (Black et al. 2011a, c; see also Adger et al. 2015). For instance, neoclassical economists emphasize that potential migrants calculate their expected earnings in their place of origin in comparison with various destinations (Lilleør and Van den Broeck 2011; Harris and Todaro 1970; Todaro 1969). Or it is contended that migration decisions are taken by the household as a whole as part of its survival strategy, since migration of a household member is seen as a way for the household to minimize risks and maximize its chances of survival under conditions of economic uncertainty by diversifying its sources of income (Stark and Lucas 1988; Stark and Bloom 1985; Stark and Levhari 1982). Sociologists highlight migrant networks and a "culture of migration" (Kandel and Massey 2002; Massey 1990a), while political scientists primarily stress political instability and violence as driving migration (Raleigh 2011; Salehyan and Gleditsch 2006).

To the extent that environmental factors are considered in these studies, they are regarded as either "stressors" or "locational characteristics" that influence the likelihood of migration (Adger et al. 2015; Hunter et al. 2015; Lilleør and Van den Broeck 2011; Knapp and Graves 1989; Speare 1974; Wolpert 1966). According to the "stress-threshold" model (Wolpert 1966; see also Bardsley and Hugo 2010), environmental events, such as floods or droughts, can act as "stressors" that affect 
individuals' life satisfaction. Not surprisingly, a growing number of studies demonstrate that disruptions in climatic and environmental conditions are associated with non-negligible changes in individuals' happiness and life satisfaction (e.g., Maddison and Rehdanz 2011; Luechinger and Raschky 2009; Ferrer-i-Carbonell and Gowdy 2007). Environmental stress should then be more important in areas prone to natural disasters and/or where people are directly dependent on the natural environment for their livelihood, e.g., when individuals depend on rain-fed agriculture.

When subscribing to the claim that environmental stressors affect personal income and the opportunity for future employment negatively, ${ }^{5}$ thereby reducing life satisfaction, we argue that the individual might consider migration to places with better environmental attributes as a response. However, we submit that migration is not a "default" response to environmental change. Migration is costly, in both financial and sociological/psychological terms, since individuals tend to develop strong personal bonds with their home location over the course of their life (Adams and Adger 2013; Penning-Rowsell et al. 2013; Devine-Wright 2013; Lewicka 2011; Mortreux and Barnett 2009). Consequently, an individual will consider migration only when (1) environmental change has a major impact on her personal well-being, while (2) the individual's efforts to adapt to and/or mitigate this impact have failed or are likely to fail in the future (see also Penning-Rowsell et al. 2013; Bardsley and Hugo 2010; Speare 1974). If the environment has a major impact and adaptation is unlikely to succeed, ${ }^{6}$ the costs of migration are lower than the costs of staying at a given location, and, hence, migration becomes an adaptation strategy to environmental change (Adger et al. 2015, 2009; Black et al. 2011; Bardsley and Hugo 2010).

In line with other studies (e.g., Hunter et al. 2015; Black et al. 2011c), we emphasize that migration decisions are likely to be affected to a large degree by individual perceptions of environmental change, rather than environmental change identified objectively with "scientific risk analysis, performed by experts, of system characteristics of the physical or social world" (e.g., Dessai et al. 2004: 11). Environmental perception is the means by which individuals seek to understand their environment in order to arrive at a more effective response to environmental hazards. Environmental perception encompasses both direct experience of the environment and indirect information from other people, science, and the mass media, which are in turn mediated by individual values, roles, and attitudes. In this

\footnotetext{
5 Beegle et al. (2011), using micro-data from Tanzania, report that rainfall shocks increase the probability that people leave their villages. Similarly, Barrios et al. (2010) find that rainfall shortages raise rural outmigration in Sub-Saharan Africa. Lilleør and Van den Broeck (2011), on the other hand, provide a critical review of the existing theoretical and empirical research on how climate change and climate variability in less developed countries (LDCs) could affect migration via their effect on personal income.

${ }^{6}$ Burke and Emerick (forthcoming) and Dell et al. (2014) provide evidence for limited adaptation among farmers. Unfortunately, our survey data lack a temporal dimension, and we thus cannot say much about the effectiveness of the adaptation strategies our survey respondents implemented. We can report, however, that almost all respondents implemented at least one adaptation measure after they had experienced the environmental event mentioned in their questionnaire. In addition, existing literature does, in fact, provide evidence that perceptions of climatic changes such as changes in temperature are associated with a higher probability to implement some type of adaptation strategy, for example, Gourdji et al. (2015) for Nicaragua; Di Falco and Veronesi (2013) for Ethiopia; Bryan et al. (2013) for Kenya; Below et al. (2012) for Tanzania; Seo et al. (2010) for South America; Chinvanno et al. (2008) for Vietnam.
} 
sense, perceptions of (environmental) risk can act as a "mediating factor" between environmental change and migration (Bardsley and Hugo 2010; Hunter 2005; Dessai et al. 2004). And it is likely that perceptions of environmental change along with individual characteristics related to their (perceived) adaptive ability-and institutional opportunities and constraints - may be better able to explain why some people leave their homes when facing environmental threats, while others do not (Black et al. 2011c, 2013; Mortreux and Barnett 2009).

Environmental change tends to have an asymmetric impact across the affected population, implying that while some individuals might be negatively affected by an environmental event — or at least perceive it that way-others could have a different perception of this. Research employing individual-level data on a sample of African farmers, for example, shows that higher annual temperatures are associated with positive net revenues for livestock owners, but negative net revenues for crop producers (CEEPA 2008). Furthermore, perceptions of environmental change are almost by definition relative, influenced by the ability of an individual to cope with and adapt to environmental change, i.e., willingness and opportunity aspects (see Most and Starr 1989). The range of adaptive options varies among individuals depending on attributes of the individual or her household, e.g., work skills, age, gender, education, or wealth. Piguet et al. (2011) and Black et al. (2011c), among others, argue that individuals who have access to resources are more likely to be able to adapt to the challenges of climatic change. Consequently, perceptions of environmental change are shaped not only by a respective individual's actual exposure to it, but also by her adaptive capacity, i.e., the possibilities and opportunities to cope with it (see also Grothmann and Patt 2005).

Next to placing individual-level perceptions of environmental change at the center of our theory and the empirical analysis, we further argue that the specific characteristics of environmental change affect the decision to migrate or stay. In terms of these characteristics, we focus on the distinction between sudden (shortterm) and slow-onset, gradual (long-term) environmental events (see also McLeman 2014; Black et al. 2011c, 2013; Renaud et al. 2011). Sudden (short-term) environmental events, such as floods, storms, and hurricanes, can have severe impacts - at least in the short-run — on the well-being of individuals. These events cause casualties or injuries, property (e.g., houses, machinery, crops, etc.) damage, or social and economic disruption. Such events are likely to produce the greatest behavioral response, because they are above the perceptual threshold of direct human experience and are easily recognizable as extreme events with the potential to inflict a lot of (human and property) cost on individuals. Affected individuals may, thus, migrate in the aftermath of such environmental events, as the costs of migration are lower than the costs of staying at this location. The empirical implication of this is summarized in the following hypothesis ${ }^{7}$ :

\footnotetext{
7 Migration in the presence of short and sudden environmental events tends to be over a relatively short distance, temporary, and internal (Hunter et al. 2015; Gray and Mueller 2012a, b; Black et al. 2011b, c; Myers et al. 2008; Raleigh et al. 2008). Due to the lack of a temporal dimension in our survey, we are unable to determine whether migration is temporary or permanent, though. That said, our sampling procedure of migrants ensures, to some extent, that migration is a more permanent phenomenon in our data. See the discussion on the sampling procedure below.
} 
Hypothesis 1 Perceptions of sudden (short-term) environmental events positively affect individuals' decisions to migrate.

In contrast, slow-onset and long-term environmental events, e.g., droughts, desertification, or water/land salinity, even in the presence of short-term seasonal and/or annual variability, are not usually regarded as extreme enough to be significant, because they are likely to have a smaller (immediate) impact on individuals. Consequently, people will try to adjust their productive strategies over time when experiencing such environmental events. Individuals' responses include, for instance, investments in irrigation systems, the use of drought or water-resistant plant and animal varieties, or the diversification of income sources. Subscribing to the (anticipated) implementation of these strategies, this is likely to weaken the relationship between environmental change and migration. In addition, strong ties to the current location are likely to offset potential immediate motivations to migrate, and the personal characteristics of the individual are a major determinant as well. Hence, we expect:

Hypothesis 2 Perceptions of slow-onset, long-term (gradual) environmental events are unlikely to positively affect individuals' decisions to migrate.

Finally, derived from the previous discussion and in light of the literature highlighting the importance of other levels of analysis (e.g., Adger et al. 2015; Hunter et al. 2015; McLeman 2014; Black et al. 2011b), the effect of environmental change on migration is likely to vary with country-level influences such as economic development as well as the political capacity of the government to effectively address environmental problems (Adger et al. 2009). Although individuals may be willing to respond to environmental changes by, for example, developing adaptation strategies, their ability to do so critically depends on the availability of the technological and economic resources for developing innovations. Consequently, to the extent that a state's economic development conditions individuals' migration decisions, we expect richer countries to be more likely to deal with and adapt to environmental problems, which in turn is associated with less environmental migration.

Adaptation and coping strategies are also a function of the political environment, which assists in promoting responses to environmental change. Relative to autocracies, democratic countries should experience less environmental migration as democratic leaders have the incentive to provide economic support, infrastructure, and social services to their citizenry for alleviating environmental hardship as a means to survive in office (e.g., Bueno de Mesquita et al. 2003). Thus, while individuals in different countries may be exposed to similar environmental events, the institutional and economic context in which environmental stress occurs may not only mitigate the hazard, but also influence individuals' perceptions of environmental risk. Eventually, we seek to examine a last hypothesis:

Hypothesis 3 Economic development and a democratic form of government are likely to negatively affect individuals' decisions to migrate. 


\section{Research design}

\section{Survey overview}

For a systematic analysis of whether environmental events influence individuals' decision to move, we require data for both migrants and non-migrants who originally come from the same area. Only when comparing individuals who have stayed in an affected area with those who have left, we can isolate the effect of environmental stressors on the decision to migrate, since comparing individuals from the same region ensures that the context for all individuals, non-migrants and migrants, is similar. Therefore, this research relies on original survey data specifically collected for this purpose that allow for a quantitative analysis of individual-level migration decisions. ${ }^{8}$

To this end, we conducted an individual-level survey in five countries: Vietnam, Cambodia, Uganda, Nicaragua, and Peru over 2013-2014. Our surveys yielded 3689 completed questionnaires in total of which about $50 \%(N=1854)$ stem from migrants. The five case study countries were chosen according to the following criteria: (1) countries have been regularly affected by weather-related events (storms, floods, droughts, etc.) and are also vulnerable to future climatic change (Kreft and Eckstein 2014; ND-GAIN 2013; EM-DAT/OFDA/CRED 2013; World Bank 2013); (2) countries come from different regions of the world (Southeast Asia, Sub-Saharan Africa, and Central and Latin America) ${ }^{9}$; and finally, (3) since our theory postulates different individual reactions to slow-onset/long-term vs. suddenonset/short-term environmental events, countries contain different regions experiencing these types of stressors in order to disentangle the effects of the two types of environmental events. Based on these criteria, we believe that our five sample countries provide an ideal testing ground for our theory.

Based on information obtained from the EM-DAT/OFDA/CRED International Disaster Database and archive research, we first identified relevant regions/ provinces in each survey country that are mainly characterized by one particular environmental stressor (classified either as slow-onset/long-term or sudden-onset/ short-term environmental event). ${ }^{10}$ We then randomly chose the departments/ districts for the location of the survey. Table 4 in "Appendix" provides the locations of the surveys. Finally, we randomly selected communes or villages in these departments or districts by using a grid system with random starting points in which the interviews of the non-migrants took place.

\footnotetext{
8 The Environmental Change and Forced Migration (EACH-FOR) project is the only other data on the environment-migration nexus with surveys carried out in 23 countries in six regions worldwide (Laczko and Aghazarm 2009; see also Warner 2011). Unlike our data, however, the EACH-FOR data focus on migrants only for most countries and comprise a relatively low number of cases (individuals) per state.

9 While we sought to cover different regions of the world that may be particularly vulnerable to climate change, the selected countries are not representative of a particular region or continent.

${ }^{10}$ Note that there is no variation on the presence of environmental stressors, i.e., everyone experiences environmental stress. However, since we are not interested in objectively present environmental stress, but rather perceptions of and attitudes toward environmental stress, our research design is appropriate. In essence, only with an environmental stressor present, people can perceive it as a reason for migration (or not). We return to this issue in the robustness section.
} 
In contrast, a random sampling of migrants is hardly possible, since (by definition) they do not live in the same commune as the non-migrants any longer. Furthermore, in the locations they have migrated to, we do not know ex ante whether a specific person has migrated from the relevant areas. Hence, we relied on a "chain-referral" process (see also Laczko and Aghazarm 2009) to identify individuals who came from the exact same locations as the non-migrants, but who now live in the nearest major city, usually the provincial/regional capital and/or the national capital. Furthermore, potential migrant interviewees had to fulfill the following criteria: (1) They should have migrated out of the environmentally affected areas at age 18 or above; (2) they were not seasonal migrants; (3) they considered themselves as residents of this new location; and (4) their economic situation/livelihood was derived from this new location. Starting points of the chain referral were obtained by asking the non-migrant interviewees as well as the identified migrants in the cities whether they knew of any individuals who had left their commune or district after experiencing the same environmental event(s) and did not belong to the same household. In total, we sought to obtain the same number of migrants to match the non-migrants in each district.

All interviews were personal interviews consisting of both closed and openended questions that lasted for about $30 \mathrm{~min}$. We asked all individuals about their experience with the latest environmental event as well as certain personal information, such as age, profession, or education, as well as household-specific questions. The relevant parts of the questionnaire are listed in "Appendix."

\section{Operationalization of dependent variable and explanatory items}

Migration, our dependent variable, receives the value 1 for those individuals who decided to migrate and 0 for those who decided to stay. ${ }^{11}$ The distribution of this variable for each individual country is summarized in "Appendix": 1835 individuals in our sample are non-migrants, while 1854 migrants are included. Hence, our sample is basically balanced for the dependent variable. When designing and implementing the survey, we anticipated that it would be difficult to ask individuals about events in their past, as it is the case with any other similar project. Furthermore, the longer the time horizon into the past for which the respondents should provide answers, the more likely the problem of recall bias is. Recall bias, however, is unlikely to be a major issue in our case at least due to the following three reasons: First, the mentioned environmental event(s) should have such a great scope and thus importance that they should easily come to mind. Second, individuals in this first step had only to recall whether an event occurred and not when exactly the particular event occurred. Finally, respondents could name any

\footnotetext{
11 Recent literature suggests that a better understanding of environmental migration requires distinguishing between three possible outcomes of environmental events: migration, displacement, and immobility (see Black et al. 2013; Black and Collyer 2014). This distinction clearly matters, and we incorporate immobility in the dependent variable (Migration $=0$ ). Due to the lack of data, however, we leave a thorough examination of the displacement outcome to future research, but we also believe that we consider this at least partly since democracy and economic development should condition displacement as well. See also footnote 4 above on this.
} 
event that occurred in the last five years which includes, of course, the recent past, which is extremely important to us and most likely should be remembered the best.

Our two main independent variables on perception of environmental change pertain to sudden/short-term and slow-onset/long-term events, respectively. For capturing this, we asked respondents — both migrants and non-migrants - to describe the main weather events they experienced over the past five years. Respondents could choose between several weather events such as heavy rain, storms and floods, or drought and salinity, but could also list any other weather event that was not listed in the questionnaire, or were able to state that no weather events have occurred in the recent past. If individuals mentioned that they experienced any heavy rain, storm, flood, hail/snow, hurricane, cyclone, typhoon, and/or landslide/mudslide, we coded this event as sudden and short-term environmental event. In contrast, we coded salinity, drought, or desertification as slow-onset and gradual long-term environmental event.

We also consider several control variables, taken from our survey, that are also included in other studies of individual-level migration decisions. First, there are respondents' gender and age, since women as well as older individuals are typically less likely to migrate (Hunter et al. 2015: 7f). Particularly controlling for gender addresses an empirical gap Hunter et al. (2015: 13) identify. Following recent explanatory models of migration networks emphasizing that migration decisions are made in a broader socioeconomic context, we also incorporate a binary variable on whether another household member has previously migrated. Such networks increase the likelihood that relatives and friends will follow once the first migrant has settled in her/his new location by sharply reducing the costs and risks associated with migration (Massey 1990b; see also Hunter et al. 2015).

To control for potential economic reasons of migration, we rely on four different proxy variables, which we introduce into our models separately due to collinearity issues. First, we consider a respondent's level of education. Given that education can determine employment opportunities, it is often assumed that people with a low level of education tend to be more reliant on environment-dependent activities, such as agriculture, and are then more vulnerable to environmental changes; consequently, they should exhibit a higher propensity for migration (Van der Land and Hummel 2013). On the other hand, due to our sampling strategy, which mostly captures rural-to-urban migration, we might observe the opposite effect. Since urban areas are a more attractive destination for individuals with higher levels of education, these individuals could be more likely to migrate. We measure education via three dummy variables: Whether a respondent has no formal education, whether a respondent received at maximum primary education, or whether a respondent received at maximum secondary education. Individuals with higher education levels serve as the baseline category.

Second, there is the interviewers' classification of the respondents' economic household status. While the ability to move is strongly related to wealth to the extent that under adverse environmental conditions wealthy people are generally more able to move (Black et al. 2013), the "conventional narrative" often advanced in public and policy debates posits that the poor and vulnerable are most likely to migrate in the face of environmental problems (Gray and Mueller 2012b), often leaving 
vulnerable women and children behind (Penning-Rowsell et al. 2013: s44). In light of this, interviewers classified whether a household is economically below average, at average, or above average. We constructed two dummy variables-below and above average-based on this information, while those individuals with an average economic status serve as the baseline category. ${ }^{12}$

Third, we use the respondents' self-assessment as to whether economic issues influenced their decision to migrate or not. In particular, all migrants were asked about their reasons to migrate and they could choose between, for example, social, political, environmental, or economic ones. For all respondents who stated that economic reasons contributed to their decision to migrate, we assigned the value of 1 to the variable Economic Reason (0 otherwise). Since we could not ask the nonmigrants the same question, we asked them whether they have ever thought about migrating from their location and, if so, which were the reasons for doing so. For those respondents who stated that they thought about migrating due to economic reasons, the Economic Reason also receives a value of 1 (0 otherwise). However, this self-assessment might be problematic, since individuals might want to overestimate or underestimate certain factors due to personal reasons (e.g., nonmigrants might not want to admit that they do not do well economically).

The final variable to control for the opportunity costs of migration captures a respondent's profession as a proxy for economic well-being. The expectation here is that individuals, whose livelihood directly depends on the natural environment such as farmers, are more likely to move in the presence of adverse environmental conditions. We include the following five professions in our models, while individuals working in the agriculture sector are the baseline category: civil servants, individuals living from business sales, workers (industry, handicrafts, etc.), individuals with elementary professions such as day labor, and individuals living from remittances or other sources of income. ${ }^{13}$

\section{Empirical findings}

How do perceptions of and attitudes toward short-term and long-term environmental events affect individuals' decision to migrate? We analyze the pooled data of our five countries and rely on a multi-level regression framework that further allows us to control for influences beyond the individual level. This approach is likely to provide us with an overall assessment as to whether and how environmental events, on average, indeed increase migration.

We use a random-intercept approach that accounts for the hierarchical sampling procedure within countries. As described above, we deliberately chose specific regions in each of the countries and then relied on random sampling below this level. Hence, we must control for the fact that certain sub-state (regional) or

\footnotetext{
${ }^{12}$ In terms of education and poverty, the results are virtually identical when using the original ordinal variable instead of the binary items and when both original ordinal variables are included in the same model.

13 The "Appendix" reports the corresponding descriptive statistics.
} 
country-specific factors might affect our results. For example, Hunter et al. (2015: 5) point to influences stemming from "a region's historical-political context." To this end, we incorporate a country-level as well as a regional-level intercept in each of the models in Table 1, which accounts for the specific hierarchical, two-level nature of the pooled data set (Rabe-Hesketh and Skrondal 2009). ${ }^{14}$ Both intercepts are modeled according to a normal distribution (Gelman and Hill 2007). ${ }^{15}$

The findings suggest that long-term, gradual environmental events, such as droughts or salinity, do not lead to migration; in fact, they even decrease the likelihood of it significantly. This finding is consistent with our theoretical argument that people are unlikely to migrate in response to longer-term environmental stressors, since they are tied to their location and, hence, adaptation might be the preferred option. It is worth noting that almost all of the survey respondents implemented at least one adaptation measure after having experienced a long-term environmental event. Adaptation strategies more often mentioned include substitute crop/switch animal type, change variety of crop, change sowing/planting dates, irrigate the land, sell assets, utilize moneylenders, and supply labor. In contrast, short-term, sudden-onset environmental events, such as storms or floods, raise the likelihood of migration. While we consistently obtain a positive coefficient estimate for sudden environmental events, note that it only reaches conventional levels of statistical significance in two out of the four models of Table 1. That is, when relying on the more subjective measures of economic motives of migration, i.e., interviewers' assessment of household type and individual self-assessment of economic reasons to migrate, the coefficient is not significant. A possible explanation for this result might be the high costs and uncertainties associated with moving, even temporarily.

As the coefficients in the hierarchical models for binary variables we employ cannot be interpreted directly, we also calculated predicted probabilities for Migration $=1$ and first differences for Sudden Events and Graduals Events, i.e., the change in the probability of migration when raising either environmental threat variable from 0 to 1 while holding all other variables constant at their observed values. Figures 1 and 2 display these substantive effects. As Fig. 1 shows, the probability of migration is about $60 \%$ in the presence of sudden events, while only about $48 \%$ when individuals perceived the onset of a gradual environmental. Figure 2 presents the substantive impact in a more intuitive way: The first differences show that changing Gradual Events from 0 to 1 decreases the likelihood of migration by up to 10 percentage points. For Sudden Events, the first differences are mixed across the models in Table 1, which mirrors the insignificance in half of the models in that table.

\footnotetext{
14 Our results are robust across different specifications of the structure of the covariance matrix for the random effects, including when allowing all variances and covariances to be distinct. The findings also remain unchanged when employing a linear probability model (LPM) with regional fixed effects. We thank an anonymous reviewer for this suggestion.

15 One could further argue that migratory decisions are correlated within villages. To control for this possibility, we run models with bootstrapped standard errors clustered on villages. The main results of our analysis stay the same. Results are available upon request.
} 
Table 1 Determinants of environmental migration: multi-level logistic regression models

\begin{tabular}{|c|c|c|c|c|}
\hline & Model 1 & Model 2 & Model 3 & Model 4 \\
\hline Sudden events & $\begin{array}{l}0.40 * * * \\
(0.114)\end{array}$ & $\begin{array}{l}0.10 \\
(0.121)\end{array}$ & $\begin{array}{l}0.12 \\
(0.136)\end{array}$ & $\begin{array}{l}0.39 * * * \\
(0.112)\end{array}$ \\
\hline Gradual events & $\begin{array}{l}-0.62 * * * \\
(0.107)\end{array}$ & $\begin{array}{l}-0.36^{* * *} \\
(0.115)\end{array}$ & $\begin{array}{l}-0.67 * * * \\
(0.133)\end{array}$ & $\begin{array}{l}-0.69 * * * \\
(0.106)\end{array}$ \\
\hline Female & $\begin{array}{l}0.21 * * \\
(0.087)\end{array}$ & $\begin{array}{l}0.29 * * * \\
(0.094)\end{array}$ & $\begin{array}{l}0.33 * * * \\
(0.106)\end{array}$ & $\begin{array}{l}0.11 \\
(0.085)\end{array}$ \\
\hline Age & $\begin{array}{l}-0.06 * * * \\
(0.004)\end{array}$ & $\begin{array}{l}-0.06 * * * \\
(0.004)\end{array}$ & $\begin{array}{l}-0.08 * * * \\
(0.005)\end{array}$ & $\begin{array}{l}-0.08 * * * \\
(0.004)\end{array}$ \\
\hline Household member migrated & $\begin{array}{l}0.35 * * * \\
(0.088)\end{array}$ & $\begin{array}{l}0.38 * * * \\
(0.095)\end{array}$ & $\begin{array}{l}0.33 * * * \\
(0.108)\end{array}$ & $\begin{array}{l}0.41 * * * \\
(0.088)\end{array}$ \\
\hline No education & $\begin{array}{l}-1.69 * * * \\
(0.211)\end{array}$ & & & \\
\hline Primary education & $\begin{array}{l}-2.07 * * * \\
(0.147)\end{array}$ & & & \\
\hline Secondary education & $\begin{array}{l}-1.58 * * * \\
(0.123)\end{array}$ & & & \\
\hline Poor household & & $\begin{array}{l}-1.03 * * * \\
(0.134)\end{array}$ & & \\
\hline Rich household & & $\begin{array}{l}0.72 * * * \\
(0.178)\end{array}$ & & \\
\hline Economic reason & & & $\begin{array}{l}3.34 * * * \\
(0.114)\end{array}$ & \\
\hline Civil servant & & & & $\begin{array}{l}-0.56 * * * \\
(0.187)\end{array}$ \\
\hline Business sales & & & & $\begin{array}{l}-0.53 * * * \\
(0.115)\end{array}$ \\
\hline Craft and trade workers & & & & $\begin{array}{l}-1.36^{* * *} \\
(0.151)\end{array}$ \\
\hline Elementary occupation & & & & $\begin{array}{l}-0.79 * * * \\
(0.131)\end{array}$ \\
\hline Other sources of income & & & & $\begin{array}{l}-0.53 * * \\
(0.257)\end{array}$ \\
\hline Constant & $\begin{array}{l}3.52 * * * \\
(0.541)\end{array}$ & $\begin{array}{l}2.46 * * * \\
(0.603)\end{array}$ & $\begin{array}{l}1.14 * * \\
(0.454)\end{array}$ & $\begin{array}{l}3.23 * * * \\
(0.438)\end{array}$ \\
\hline Country variance & $\begin{array}{l}0.53 \\
(0.890)\end{array}$ & $\begin{array}{l}0.86 \\
(1.108)\end{array}$ & $\begin{array}{l}0.00 \\
(0.000)\end{array}$ & $\begin{array}{l}0.00 \\
(0.000)\end{array}$ \\
\hline District variance & $\begin{array}{l}4.01 * * * \\
(1.547)\end{array}$ & $\begin{array}{l}4.04 * * \\
(1.572)\end{array}$ & $\begin{array}{l}4.18 * * * \\
(1.511)\end{array}$ & $\begin{array}{l}4.16^{* * * *} \\
(1.473)\end{array}$ \\
\hline Observations & 3614 & 3125 & 3625 & 3477 \\
\hline
\end{tabular}


Table 1 continued

\begin{tabular}{lllll}
\hline & Model 1 & Model 2 & Model 3 & Model 4 \\
\hline Number of groups (countries) & 5 & 5 & 5 & 5 \\
Log likelihood & -1784.51 & -1545.24 & -1310.41 & -1807.08 \\
Wald $^{2}$ & $658.62^{* * *}$ & $370.51^{* * * *}$ & $1006.68^{* * * *}$ & $554.26^{* * *}$ \\
\hline
\end{tabular}

Table entries are coefficients from multi-level logistic regression models with country-level and districtlevel random effects; standard errors in parentheses

*** Significant at $1 \%$; ** significant at $5 \%$; significant at $10 \%$
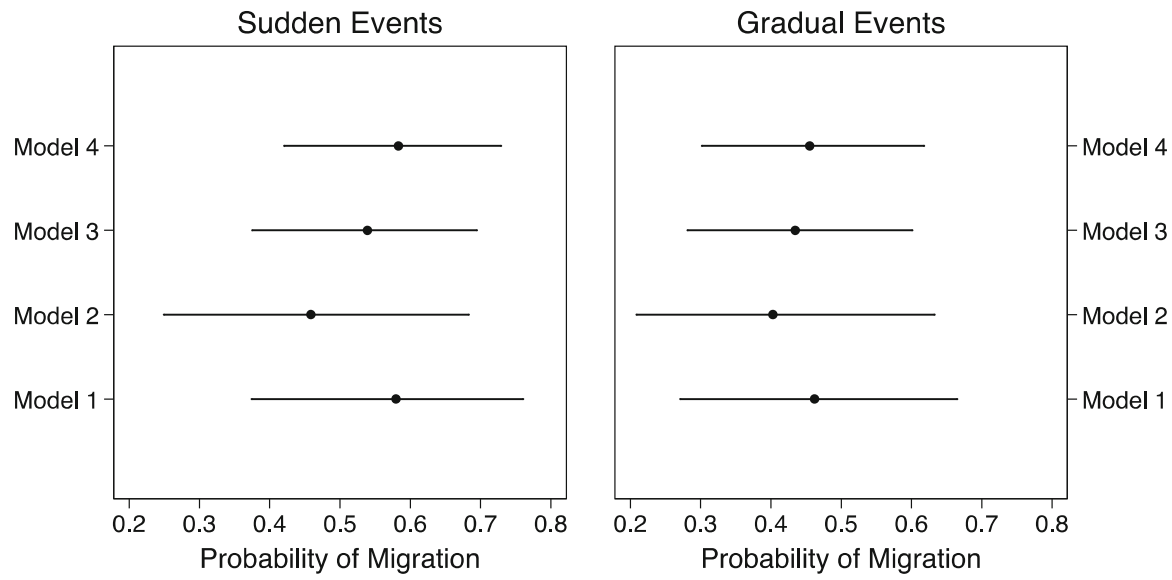

Fig. 1 Probability of migration. Graph shows predicted probabilities for Migration $=1$; horizontal bars pertain to $90 \%$ confidence intervals; left panel captures probabilities for Sudden Event $=1$, while right panel pertains to probabilities for Gradual Event $=1$; all other variables held constant at their means; calculations are based on Table 1 and include both fixed and random effects

The control variables are mostly in line with earlier studies (see, e.g., Hunter et al. 2015) and our expectations. While older individuals are less likely to migrate, respondents of which a household member has already migrated are more likely to move to a new location as well. This latter finding and its corresponding variable not only control for a household effect (Massey 1990a, b; see also Hunter et al. 2015), but also suggest that migration is a more permanent phenomenon in our sample. That is, given that migration by a household member is clearly associated with some costs, the decision of another household member to follow is likely to be undertaken only when the decision to migrate is permanent. In addition, the effect of gender highlights that women are actually more likely to migrate (see also Gray and Mueller 2012a). It thus seems that gender plays a complex role in the process of environmental migration (Hunter et al. 2015), but may be easily explained in our sample that focuses on rural-to-urban migration: Job opportunities for women are 


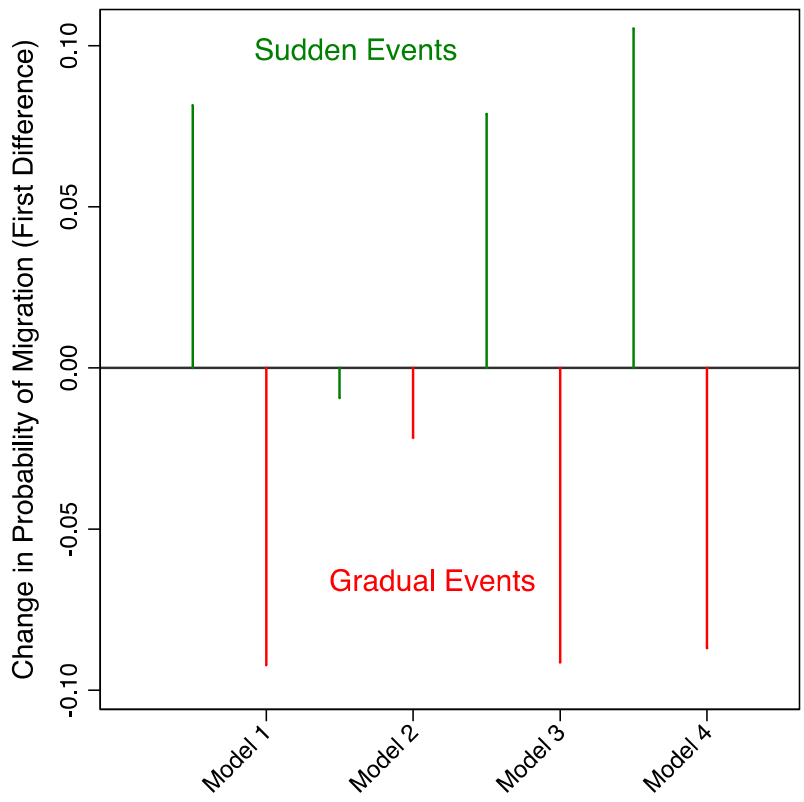

Fig. 2 First differences. Graph shows changes in the probability of Migration $=1$ when changing either Sudden Events (green bars) or Gradual Events (red bars) from 0 to 1, while holding all other variables at their observed values; calculations are based on Table 1 and include both fixed and random effects

more likely to exist in urban areas, which then lower the costs of the initial migration decision. ${ }^{16}$

With regard to the economic reasons for migration, Model 1 suggests that individuals with lower levels of education than our baseline category (higher education) are less likely to migrate. This matches the interpretation that those individuals who most likely have better job opportunities due to their advanced education are more likely to look for these opportunities in a location other than their original place (see also Docquier et al. 2007; Beine et al. 2008). Given our sampling strategy, which mostly captures rural-to-urban migration, this finding might be more pronounced than in studies examining urban-to-urban or rural-torural migration. Similarly, Model 2 shows that individuals who are assessed to live in a wealthy household are more likely to migrate than individuals who come from an average-level household (baseline category), and individuals who are assessed to live in a poor household are less likely to move. The latter finding supports Black and Collyer's (2014) argument about "trapped populations," i.e., populations that are vulnerable to environmental stress, but lack the resources to move. In Model 3, we rely on individual self-assessment on whether economic reasons are/were an

\footnotetext{
${ }^{16}$ Examining the results by country suggests that a positive and significant effect is only found in Nicaragua and Peru, while we observe a negative coefficient for the other countries (although only significantly different from 0 in Uganda). There is also little evidence that women following their husbands, i.e., dependent migration, can explain the positive effect of female migration. Hence, better job opportunities in cities are likely to be the driver behind women migration in Nicaragua and Peru.
} 
important driver of migration. The effect of this variable strongly supports the idea that economic reasons are a major force behind individuals' decision to migrate. Finally, Model 4 stresses that individuals with a profession other than our baseline category (agriculture) are less likely to migrate. This result provides some support to the assertion that environmental stress is more likely to be felt by individuals who are directly dependent on the natural environment for their livelihood and, hence, the ones who are more likely to decide to move under adverse climatic conditions.

By incorporating a country-level random intercept, we control for the fact that we study internal migration in five different country contexts. However, one could model these diverse circumstances more directly by including relevant factors that affect migration patterns within states. Two variables seem most relevant from this perspective: the political system and a country's economic development. Both items could influence a country's capability to react to environmental stressors and, thus, individuals' decision to stay or migrate. Our findings for this are summarized in Table 2, which mirrors Table 1, but we now include a variable on a country's political system, measured by the polity 2 item from the Polity IV data (Marshall, Gurr, and Jaggers 2013), and GDP per capita in current US Dollars from the World Development Indicators. We use data from 2012 to ensure that both variables are measured before the surveys were conducted. The results in Table 2 show, however, that none of the country-level variables has a statistically significant effect on migration. $^{17}$

The lack of migratory responses to slow-onset events may be driven by a lack of perceptions of environmental changes, rather than adaptation strategies. ${ }^{18}$ To address this possibility, we also examined with more "objective data" whether the impact differs in areas with higher variance in weather-related phenomena. For example, households in areas with high weather variance might recognize more easily climatic changes (Dell et al. 2014). We considered a variable on temperature variance based on "NOAA's NCEP/NCAR Reanalysis Monthly Means Dataset 1948-2011" (in degrees Celsius) (Kalnay et al. 1996; see also Landis 2014) in two different ways. On the one hand, we examined whether this more "objective" variable influences respondents' perceptions of climatic events. On the other hand, we included this control as an additional explanatory variable in our models. We find that the more "objective" item does indeed influence subjective perceptions: Higher variances in temperature do indeed significantly increase the likelihood of respondents to perceive gradual events while it decreases the likelihood of

\footnotetext{
17 We do not explicitly examine interactive relationships between the determinants of migration at different levels, since Hunter et al. (2015: 9) describe these relationships as rather "additive." However, preliminary analyses suggest no clear pattern between the political system and individual reactions to the type of environmental event. Since the low number of cases at the country level (five) implies that it is difficult to calculate models with multiplicative specifications, we divide our sample along the interacted variables. Hence, we run individual regression models by countries to better understand how democracy affects the decision to engage in environmental migration. We provide the corresponding results in the "Appendix".

${ }^{18}$ We thank an anonymous reviewer for highlighting this issue.
} 
Table 2 Alternative models with multi-level logistic regression models

\begin{tabular}{|c|c|c|c|c|}
\hline & Model 5 & Model 6 & Model 7 & Model 8 \\
\hline Sudden events & $\begin{array}{l}0.40 * * * \\
(0.114)\end{array}$ & $\begin{array}{l}0.10 \\
(0.121)\end{array}$ & $\begin{array}{l}0.12 \\
(0.136)\end{array}$ & $\begin{array}{l}0.39 * * * \\
(0.112)\end{array}$ \\
\hline Gradual events & $\begin{array}{l}-0.62 * * * \\
(0.107)\end{array}$ & $\begin{array}{l}-0.36^{* * *} \\
(0.115)\end{array}$ & $\begin{array}{l}-0.67 * * * \\
(0.134)\end{array}$ & $\begin{array}{l}-0.69 * * * \\
(0.106)\end{array}$ \\
\hline Female & $\begin{array}{l}0.21 * * \\
(0.087)\end{array}$ & $\begin{array}{l}0.29 * * * \\
(0.094)\end{array}$ & $\begin{array}{l}0.33 * * * \\
(0.106)\end{array}$ & $\begin{array}{l}0.11 \\
(0.085)\end{array}$ \\
\hline Age & $\begin{array}{l}-0.06 * * * \\
(0.004)\end{array}$ & $\begin{array}{l}-0.06 \text { *** } \\
(0.004)\end{array}$ & $\begin{array}{l}-0.08 * * * \\
(0.005)\end{array}$ & $\begin{array}{l}-0.08 * * * \\
(0.004)\end{array}$ \\
\hline Household member migrated & $\begin{array}{l}0.35 * * * \\
(0.088)\end{array}$ & $\begin{array}{l}0.38 * * * \\
(0.095)\end{array}$ & $\begin{array}{l}0.34 * * * \\
(0.108)\end{array}$ & $\begin{array}{l}0.41 * * * \\
(0.088)\end{array}$ \\
\hline Democracy & $\begin{array}{l}-0.05 \\
(0.099)\end{array}$ & $\begin{array}{l}0.06 \\
(0.114)\end{array}$ & $\begin{array}{l}-0.05 \\
(0.085)\end{array}$ & $\begin{array}{l}-0.04 \\
(0.084)\end{array}$ \\
\hline GDP per capita & $\begin{array}{l}-0.00 \\
(0.000)\end{array}$ & $\begin{array}{l}-0.00 \\
(0.000)\end{array}$ & $\begin{array}{l}0.00 \\
(0.000)\end{array}$ & $\begin{array}{l}-0.00 \\
(0.000)\end{array}$ \\
\hline No education & $\begin{array}{l}-1.69 * * * \\
(0.211)\end{array}$ & & & \\
\hline Primary education & $\begin{array}{l}-2.07 * * * \\
(0.147)\end{array}$ & & & \\
\hline Secondary education & $\begin{array}{l}-1.58 * * * \\
(0.123)\end{array}$ & & & \\
\hline Poor household & & $\begin{array}{l}-1.03 * * * \\
(0.134)\end{array}$ & & \\
\hline Rich household & & $\begin{array}{l}0.73 * * * \\
(0.178)\end{array}$ & & \\
\hline Economic reason & & & $\begin{array}{l}3.34 * * * \\
(0.114)\end{array}$ & \\
\hline Civil servant & & & & $\begin{array}{l}-0.56^{* * *} \\
(0.187)\end{array}$ \\
\hline Business sales & & & & $\begin{array}{l}-0.53 * * * \\
(0.115)\end{array}$ \\
\hline Craft and trade workers & & & & $\begin{array}{l}-1.36^{* * *} \\
(0.151)\end{array}$ \\
\hline Elementary occupation & & & & $\begin{array}{l}-0.79 * * * \\
(0.131)\end{array}$ \\
\hline Other sources of income & & & & $\begin{array}{l}-0.53 * * \\
(0.257)\end{array}$ \\
\hline Constant & $\begin{array}{l}3.78 * * * \\
(0.731)\end{array}$ & $\begin{array}{l}2.47 * * * \\
(0.839)\end{array}$ & $\begin{array}{l}1.15^{*} \\
(0.624)\end{array}$ & $\begin{array}{l}3.39 * * * \\
(0.605)\end{array}$ \\
\hline Country variance & $\begin{array}{l}0.38 \\
(0.794)\end{array}$ & $\begin{array}{l}0.79 \\
(1.031)\end{array}$ & $\begin{array}{l}0.00 \\
(0.000)\end{array}$ & $\begin{array}{l}0.00 \\
(0.000)\end{array}$ \\
\hline
\end{tabular}


Table 2 continued

\begin{tabular}{lllll}
\hline & Model 5 & Model 6 & Model 7 & Model 8 \\
\hline District variance & $4.01 * * *$ & $3.98 * * *$ & $4.12 * * *$ & $4.10^{* * *}$ \\
& $(1.543)$ & $(1.544)$ & $(1.491)$ & $(1.453)$ \\
Observations & 3614 & 3125 & 3625 & 3477 \\
Number of groups (countries) & 5 & 5 & 5 & 5 \\
Log likelihood & -1784.21 & -1545.08 & -1310.23 & -1806.85 \\
Wald $^{2}$ & $658.67 * * *$ & $370.69 * * *$ & $1006.55 * * *$ & $554.37 * * *$ \\
\hline
\end{tabular}

Table entries are coefficients from multilevel logistic regression models with country-level and districtlevel random effects; standard errors in parentheses

*** Significant at $1 \%$; * significant at $5 \%$; significant at $10 \%$

Table 3 Baseline multi-level logistic regression model

Table entries are coefficients from multi-level logistic regression models with district level random effects; standard errors in parentheses

*** Significant at $1 \%$;

** significant at $5 \%$;

* significant at $10 \%$

\begin{tabular}{ll}
\hline & Model 9 \\
\hline Sudden events & 0.57 \\
Gradual events & $(0.757)$ \\
& $-0.65^{* * *}$ \\
Constant & $(0.115)$ \\
& 0.04 \\
District variance & $(0.774)$ \\
& 3.90 \\
Observations & $(5.702)$ \\
Number of groups (countries) & 3674 \\
Log likelihood & 5 \\
Wald & \\
\hline
\end{tabular}

perceiving sudden events. Moreover, our core results hold when we include the temperature-variance variable in the model.

Furthermore, Clarke $(2005,2009)$ shows that the inclusion of control variables can actually increase the bias instead of decreasing it. Table 3 then reports the results when dropping the control variables. Again, our finding that long-term environmental events are associated with a decreased likelihood, while short-term environmental events are associated with an increased likelihood of migration, is robust to the inclusion and exclusion of control variables. ${ }^{19}$

\footnotetext{
19 Moreover, this assessment is further supported by the more formal test introduced in Oster (2015). However, this applies more to Gradual Events than to Sudden Events.
} 


\section{Conclusion}

Various academics, policymakers, and public institutions suggest that one major consequence of climate change is that environmental events force millions of people to migrate permanently or temporarily. Migration on such a massive scale could lead to additional adverse outcomes, such as social unrest and armed conflict (Bernauer et al. 2012; Laczko and Aghazarm 2009; Reuveny 2007). However, despite the recent empirical progress, important knowledge gaps still remain. We seek to contribute to the existing literature by developing a theoretical argument that considers individual perceptions of different types of environmental change and their likely effects on individuals' decision to migrate.

Empirically, our research improves on existing work in at least four ways. First, we introduced new survey data from five different countries, which make our study one of the first relying on a quantitative and comparative perspective. Second, our survey allows us to distinguish between different types of environmental events. In particular, we considered both sudden-onset and long-term environmental problems for which we hypothesized different effects on migration. Third, our survey includes people who migrated and those who decided to stay, which is crucial for an understanding of whether environmental change does indeed lead to migration. Fourth, we not only include individual characteristics, but also explicitly consider household-level characteristics and country-level factors that should affect people's migration decision.

The results show that the effect of individual-level perceptions of environmental change strongly depends on the nature of the environmental event: While suddenonset environmental events, such as storms or floods, tend to increase the likelihood of migration, long-term, gradual environmental events, such as salinity or droughts, are unlikely to lead to migration but in fact decrease its likelihood. This supports our theoretical argument that individuals prefer to stay and try to adapt to an environmental problem - instead of opting for the more uncertain and costly option of migration when facing long-term environmental shocks. Our study compliments the findings of previous studies, which report that short-term environmental events can lead to migration (e.g., Gray and Mueller 2012a; Paul and Routray 2010), while we additionally provide new evidence on the nexus between long-term environmental events and migration in the context of micro-level studies.

The main policy implication of our research is that a more differentiated perspective on the issue of environmental migration is in need. Where future climatic changes manifested themselves in the form of abrupt and extreme environmental events, then large numbers of people might be forced to migrate from some areas of the world, particularly from low-altitude coastal areas in developing countries. However, if the past provides any insights into what may happen in the future, our work suggests that most people prefer to stay and deal with the environmental problem by implementing adaptation techniques, especially when faced with slow-onset, longer-term environmental events.

That said, it still might be the case that some individuals stay not because they choose to, but rather because they are unable to move due to failed adaptation measures and 
subsequent depletion of resources (Black and Collyer 2014; Foresight Project 2011). Hence, future research should examine whether and to what extent long-term environmental events lead to effective adaptation and/or entrapment. Either way, improving the supply of aid to areas affected by environmental disasters, and the financial and technical support for adaptation to environmental problems could potentially be, at least in the short-run, the most effective policy options.

Acknowledgments The authors thank two anonymous reviewers and the journal editor for their helpful comments. This research is part of the project "Environmental Change and Migration" funded by the Swiss Network for International Studies (SNIS).

\section{Appendix}

See Tables 4, 5, and 6 .

Table 4 Overview of surveys

\begin{tabular}{|c|c|c|c|c|c|}
\hline & Vietnam & Uganda & Cambodia & Nicaragua & Peru \\
\hline $\begin{array}{l}\text { Non-migrants: } \\
\text { subnational locations } \\
\text { and type of } \\
\text { environmental } \\
\text { problems }\end{array}$ & $\begin{array}{l}\text { Ba Tri } \\
\text { (salinity) } \\
\text { Chau Phu } \\
\text { (flood) } \\
\text { Giao Thuy } \\
\text { (cyclone) } \\
\text { Ninh Hai } \\
\text { (drought) }\end{array}$ & $\begin{array}{l}\text { Kotido and } \\
\text { Moroto } \\
\text { (drought, heavy } \\
\text { rain/flood) }\end{array}$ & $\begin{array}{l}\text { Cheung Prey } \\
\text { Kang Meas } \\
\text { Koh Sotin } \\
\text { Krouch } \\
\text { Chhma } \\
\text { (storm/flood/ } \\
\text { Khsach kandal } \\
\text { Koaoh Thum } \\
\text { Lvea Aem } \\
\text { S'ang } \\
\text { (flood/drought) }\end{array}$ & $\begin{array}{l}\text { Managua, } \\
\text { Chinandega, } \\
\text { and Leon } \\
\text { (drought) } \\
\text { R.A.A.N and } \\
\text { R.A.A.S } \\
\text { (storms) }\end{array}$ & $\begin{array}{l}\text { Cusco } \\
\text { (flood, } \\
\text { cold } \\
\text { weather) } \\
\text { Puno } \\
\text { (drought) } \\
\text { Piura } \\
\text { (drought/ } \\
\text { flood) } \\
\text { Arequipa } \\
\text { (flood) } \\
\text { Lima } \\
\text { (drought) }\end{array}$ \\
\hline $\begin{array}{l}\text { Migrants: } \\
\text { regional and capital } \\
\text { cities }\end{array}$ & $\begin{array}{l}\text { Hanoi } \\
\text { Ho Chi } \\
\text { Minh city }\end{array}$ & $\begin{array}{l}\text { Kampala } \\
\text { Kotido } \\
\text { Mbale }\end{array}$ & $\begin{array}{l}\text { Phnom Penh } \\
\text { Kampong } \\
\text { Cham }\end{array}$ & $\begin{array}{l}\text { Managua, } \\
\text { Leon } \\
\text { Chinandega }\end{array}$ & $\begin{array}{l}\text { Cusco, } \\
\text { Puno, } \\
\text { Piura, } \\
\text { Arequipa, } \\
\text { and } \\
\text { Lima }\end{array}$ \\
\hline Political system & $\begin{array}{l}\text { Autocracy } \\
\text { Polity IV: } \\
\quad-7\end{array}$ & $\begin{array}{l}\text { Anocracy } \\
\text { Polity IV: }-1\end{array}$ & $\begin{array}{l}\text { Anocracy } \\
\text { Polity IV: } 2\end{array}$ & $\begin{array}{l}\text { Democracy } \\
\text { Polity IV: } 9\end{array}$ & $\begin{array}{l}\text { Democracy } \\
\text { Polity IV: } \\
\quad 9\end{array}$ \\
\hline $\begin{array}{l}\text { Income-GDP per } \\
\text { capita } 2012\end{array}$ & 1755 USD & 653 USD & 946 USD & 6424 USD & 1777 USD \\
\hline $\begin{array}{l}\text { Number of } \\
\text { participants }(50 \% \\
\text { Migrants) }\end{array}$ & 1200 & 672 & 600 & 600 & 617 \\
\hline Survey period & $\begin{array}{l}\text { September- } \\
\text { October } \\
2013\end{array}$ & $\begin{array}{l}\text { September- } \\
\text { October } 2013\end{array}$ & $\begin{array}{l}\text { January- } \\
\text { February } \\
2014\end{array}$ & $\begin{array}{l}\text { March-April } \\
2014\end{array}$ & $\begin{array}{l}\text { July- } \\
\quad \text { August } \\
2014\end{array}$ \\
\hline
\end{tabular}


Table 5 Individual country data overviews

\begin{tabular}{|c|c|c|c|}
\hline Variable & Yes & No & $\mathrm{N}$ \\
\hline \multicolumn{4}{|l|}{ Vietnam } \\
\hline Migrants & 600 & 600 & 1200 \\
\hline Sudden events & 982 & 218 & 1200 \\
\hline Gradual events & 352 & 848 & 1200 \\
\hline Female & 685 & 515 & 1200 \\
\hline Family member has migrated & 459 & 739 & 1198 \\
\hline No education & 21 & 1177 & 1198 \\
\hline Primary education & 232 & 966 & 1198 \\
\hline Secondary education & 642 & 556 & 1198 \\
\hline Poor household & 300 & 479 & 779 \\
\hline Rich household & 153 & 626 & 779 \\
\hline Economic reason to migrate & 565 & 635 & 1200 \\
\hline Civil servant & 63 & 1137 & 1200 \\
\hline Business sales & 237 & 963 & 1200 \\
\hline Craft and trade workers & 125 & 1049 & 1200 \\
\hline Elementary occupations & 151 & 1049 & 1200 \\
\hline Other sources of income & 6 & 1194 & 1200 \\
\hline \multicolumn{4}{|l|}{ Uganda } \\
\hline Migrants & 353 & 319 & 672 \\
\hline Sudden events & 194 & 478 & 672 \\
\hline Gradual events & 632 & 40 & 672 \\
\hline Female & 427 & 243 & 670 \\
\hline Family member has migrated & 247 & 406 & 653 \\
\hline No education & 522 & 140 & 672 \\
\hline Primary education & 109 & 553 & 662 \\
\hline Secondary education & 15 & 647 & 662 \\
\hline Poor household & 533 & 134 & 667 \\
\hline Rich household & 23 & 644 & 667 \\
\hline Economic reason to migrate & 342 & 330 & 672 \\
\hline Civil servant & 6 & 611 & 617 \\
\hline Business sales & 145 & 472 & 617 \\
\hline Craft and trade workers & 16 & 601 & 617 \\
\hline Elementary occupations & 72 & 545 & 617 \\
\hline Other sources of income & 55 & 617 & 672 \\
\hline \multicolumn{4}{|l|}{ Cambodia } \\
\hline Migrants & 300 & 300 & 600 \\
\hline Sudden events & 567 & 33 & 600 \\
\hline Gradual events & 315 & 285 & 600 \\
\hline Female & 367 & 233 & 600 \\
\hline Family member has migrated & 339 & 260 & 599 \\
\hline
\end{tabular}


Table 5 continued

\begin{tabular}{|c|c|c|c|}
\hline Variable & Yes & No & $\mathrm{N}$ \\
\hline No education & 61 & 539 & 600 \\
\hline Primary education & 164 & 436 & 600 \\
\hline Secondary education & 147 & 453 & 600 \\
\hline Poor household & 157 & 368 & 525 \\
\hline Rich household & 86 & 439 & 525 \\
\hline Economic reason to migrate & 288 & 312 & 600 \\
\hline Civil servant & 22 & 484 & 506 \\
\hline Business sales & 89 & 417 & 506 \\
\hline Craft and trade workers & 21 & 485 & 506 \\
\hline Elementary occupations & 17 & 489 & 506 \\
\hline Other sources of income & 105 & 495 & 600 \\
\hline \multicolumn{4}{|l|}{ Nicaragua } \\
\hline Migrants & 300 & 300 & 600 \\
\hline Sudden events & 351 & 240 & 591 \\
\hline Gradual events & 176 & 415 & 591 \\
\hline Female & 350 & 250 & 600 \\
\hline Family member has migrated & 205 & 394 & 599 \\
\hline No education & 55 & 544 & 599 \\
\hline Primary education & 181 & 418 & 599 \\
\hline Secondary education & 258 & 341 & 599 \\
\hline Poor household & 536 & 64 & 600 \\
\hline Rich household & 4 & 596 & 600 \\
\hline Economic reason to migrate & 228 & 372 & 600 \\
\hline Civil servant & 63 & 537 & 600 \\
\hline Business sales & 77 & 523 & 600 \\
\hline Craft and trade workers & 131 & 469 & 600 \\
\hline Elementary occupations & 126 & 474 & 600 \\
\hline Other sources of income & 53 & 547 & 600 \\
\hline \multicolumn{4}{|l|}{ Peru } \\
\hline Migrants & 301 & 316 & 617 \\
\hline Sudden events & 497 & 114 & 611 \\
\hline Gradual events & 113 & 498 & 611 \\
\hline Female & 361 & 256 & 617 \\
\hline Family member has migrated & 199 & 410 & 609 \\
\hline No education & 23 & 594 & 617 \\
\hline Primary education & 165 & 452 & 617 \\
\hline Secondary education & 281 & 336 & 617 \\
\hline Poor household & 535 & 82 & 617 \\
\hline Rich household & 4 & 613 & 617 \\
\hline Economic reason to migrate & 221 & 396 & 617 \\
\hline
\end{tabular}


Table 5 continued

\begin{tabular}{lrrl}
\hline Variable & Yes & No & N \\
\hline Civil servant & 39 & 577 & 616 \\
Business sales & 121 & 495 & 616 \\
Craft and trade workers & 64 & 552 & 616 \\
Elementary occupations & 115 & 501 & 616 \\
Other sources of income & 33 & 584 & 617 \\
\hline
\end{tabular}

Table 6 Individual country regressions: baseline models by country

\begin{tabular}{llllll}
\hline & $(1)$ & $(2)$ & $(3)$ & $(4)$ & $(5)$ \\
& Cambodia & Vietnam & Uganda & Peru & Nicaragua \\
\hline Sudden events & $-2.28^{* * *}$ & $1.67 * * *$ & $-0.44 *$ & $-0.92^{* * *}$ & $0.56^{* * * *}$ \\
& $(0.83)$ & $(0.52)$ & $(0.26)$ & $(0.29)$ & $(0.19)$ \\
Gradual events & -0.26 & $-0.63 *$ & $-1.19 * *$ & $-1.13 * * *$ & $-0.64 * * *$ \\
Female & $(0.30)$ & $(0.37)$ & $(0.48)$ & $(0.31)$ & $(0.21)$ \\
Age & -0.02 & -0.30 & $-0.49 * *$ & $0.78^{* * *}$ & $0.90 * * *$ \\
& $(0.31)$ & $(0.32)$ & $(0.25)$ & $(0.20)$ & $(0.19)$ \\
HH member migrated & $-0.21^{* * *}$ & $-0.16^{* * *}$ & 0.01 & $-0.07 * * *$ & -0.01 \\
Economic reason & $(0.02)$ & $(0.02)$ & $(0.01)$ & $(0.01)$ & $(0.01)$ \\
& $0.50^{*}$ & $0.96 * * *$ & $-0.77 * * *$ & $0.73^{* * *}$ & 0.18 \\
Constant & $(0.30)$ & $(0.33)$ & $(0.25)$ & $(0.22)$ & $(0.20)$ \\
Log likelihood & $3.09 * * *$ & $7.12 * * *$ & $3.81 * * *$ & $1.55^{* * *}$ & $1.68 * * *$ \\
Observations & $(0.31)$ & $(0.51)$ & $(0.25)$ & $(0.21)$ & $(0.20)$ \\
\hline Stant & $6.61 * * *$ & 1.05 & -0.09 & $2.13^{* * * *}$ & $-1.14 * * *$
\end{tabular}

Standard errors in parentheses

$* p<0.10$; ** $p<0.05$; *** $p<0.01$ 


\section{Questionnaire}

Interview ID

Date:

Interviewer ID

Location: [to be filled out prior to interview]

Coordinates:

Current Weather [observed]:

Commune/Village/Town:

Number of households (HH) in

District:

village/town:

Province:

\section{Respondent: [based on observation]}

Household Status [scale determined before start of interview]

1 . Very poor

2. Poor

3. Average

4. Above average

5. Wealthy

99. N/A [Circle if interview not conducted in respondent home]

Sex of Respondent

1. Female 2. Male

\section{Interview Schedule}

How long have you lived in this location?

1. Since birth

2. [years]

99. Don't Know/Refused to Answer

Where did you come from?

Commune/Village:

District Province

Were you born there?

1. Yes

2. No

99. Don't Know/Refused to Answer

How long were you in that previous location for? years

99. Don't Know/Refused to Answer

What is the highest level of formal education you have attended? [Ask for specific number of years completed]

1. No formal education

2. Primary school Years completed

3. Secondary Years completed

4. Technical_Y Years completed

4. Post-Secondary __ Years completed

5. Other

99. Don’t know/Refused to Answer 
Could you tell us your age?

[If does not know or refuses to respond, interviewer to guess]

I will read you a list of sources of income. Could you tell us which are your (household) main source(s) of income? (Non-migrant) - I will read you a list of sources of income. Could you tell us which were your (household) main source(s) of income in your former location? (Migrant)

(Circle all mentioned. If more than one was mentioned, ask to rank them in order of importance (from 1-5, 1 the most important) (Insert number in spaces provided in question BELOW)

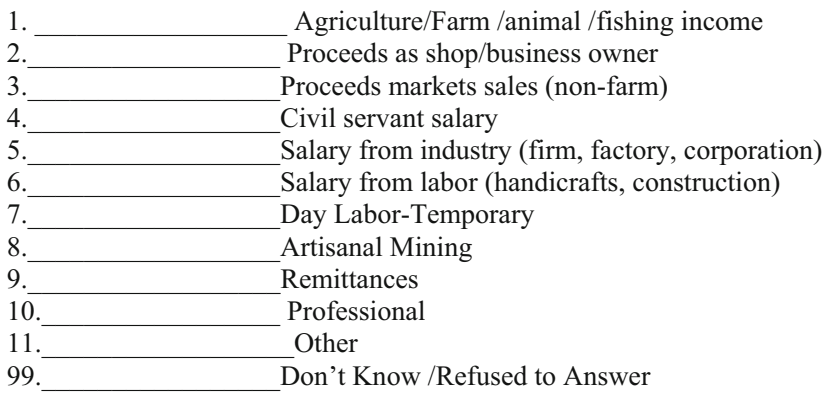

From your perspective, can you describe the main weather event(s) that have happened here during the last 5 years? (Non-migrant) - From your perspective, can you describe the main weather event(s) that occurred during the past five years before you left your previous residence? (Migrant)

[If respondent is unable to answer freely, read the list. For each reported event follow up with questions in the following table]. [Circle all that apply] Show Card

1. Heavy Rains/Floods [please circle]

2. Salinity

3. Snow/Hail [please circle]

4. Drought/Desertification [please circle]

5. Storm/Cyclone/Typhoon [please circle]

6. Landslide/Mudslide/Avalanche [please circle]

7. Other

8. None

99. Don’t Know/Refused to Answer

\begin{tabular}{|c|c|c|c|c|c|c|c|}
\hline $\begin{array}{l}\text { Circle events } \\
\text { reported in } \\
\text { previous } \\
\text { question }\end{array}$ & $\begin{array}{l}\text { 1. Heavy } \\
\text { Rain/Flood }\end{array}$ & 2. Salinity & 3. Snow/Hail & $\begin{array}{l}\text { 4. Drought/ } \\
\text { Desertificatio } \\
n\end{array}$ & $\begin{array}{l}\text { 5. Cyclone/ } \\
\text { Typhoon/ } \\
\text { Storm }\end{array}$ & $\begin{array}{l}\text { 6. Landslide/ } \\
\text { Mudslide/ } \\
\text { Avalanche/ }\end{array}$ & 7. Other \\
\hline \multirow{3}{*}{$\begin{array}{l}\text { [For short } \\
\text { term events] } \\
\text { When did this } \\
\text { event last } \\
\text { occur? } \\
\text { [Or for } \\
\text { progressive } \\
\text { environmenta } \\
\text { l events] } \\
\text { When did } \\
\text { this event } \\
\text { begin? }\end{array}$} & & & & & & & \\
\hline & $\overline{\text { Month }}$ & Month & Month & Month & Month & Month & Month \\
\hline & $\begin{array}{l}\text { Year } \\
\text { 99. DK/RA }\end{array}$ & $\begin{array}{l}\text { Year } \\
\text { 99. DK/RA }\end{array}$ & $\begin{array}{l}\text { Year } \\
\text { 99. DK/RA }\end{array}$ & $\begin{array}{l}\text { Year } \\
\text { 99. DK/RA }\end{array}$ & $\begin{array}{l}\text { Year } \\
\text { 99. DK/RA }\end{array}$ & $\begin{array}{l}\text { Year } \\
\text { 99. DK/RA }\end{array}$ & $\begin{array}{l}\text { Year } \\
\text { 99. DK/RA }\end{array}$ \\
\hline $\begin{array}{l}\text { How long did } \\
\text { this event } \\
\text { last? }\end{array}$ & $\begin{array}{l}\text { 1. days } \\
\text { 2. weeks } \\
\text { 3. months } \\
\text { 4. years } \\
\text { 99. DK/RA } \\
\end{array}$ & $\begin{array}{l}\text { 1. days } \\
\text { 2. weeks } \\
\text { 3. months } \\
\text { 4. years } \\
\text { 99. DK/RA }\end{array}$ & $\begin{array}{l}\text { 1. days } \\
\text { 2. weeks } \\
\text { 3. months } \\
\text { 4. years } \\
\text { 99. DK/RA }\end{array}$ & $\begin{array}{l}\text { 1. days } \\
\text { 2. weeks } \\
\text { 3. months } \\
\text { 4. years } \\
\text { 99. DK/RA } \\
\end{array}$ & $\begin{array}{l}\text { 1. days } \\
\text { 2. weeks } \\
\text { 3. months } \\
\text { 4. years } \\
\text { 99. DK/RA }\end{array}$ & $\begin{array}{l}\text { 1. days } \\
\text { 2. weeks } \\
\text { 3. months } \\
\text { 4. years } \\
\text { 99. DK/RA } \\
\end{array}$ & $\begin{array}{l}\text { 1. days } \\
\text { 2. weeks } \\
\text { 3. months } \\
\text { 4. years } \\
\text { 99. DK/RA }\end{array}$ \\
\hline
\end{tabular}


Have you ever thought about migrating? If yes, then ask: What was/were the reason(s)? (Nonmigrant) - I would like to ask you all the reason(s) why you decided to move from your former location. (Migrant)

[Allow respondents to answer without reading list and circle all responses in "Unprompted Column". Then follow up by reading list/Show Card. Additional responses should be circled in "Prompted Column"]

Social reasons: for example, Marriage; There are family/relatives in the new location; I was facing discrimination; There was insecurity (physical \&/or sexual); To seek health care (inadequate health care in area); To seek schooling (e.g. no school in area); Other

Economic reasons: for example, Not enough income from livelihood sources; Unreliable harvest;

No land available for farming/agriculture; Crop failure; Unemployment in that location; Job opportunity in new place; Higher income in new place; Other

Environmental reasons: for example, Water shortage/Drought [1 event]; Repeated droughts /Long Term salinity; Too much water; Short term events such as flood, storm, landslide, cyclone: Single event or Repeated Event; Other

Political reasons: for example, There was conflict; To seek political freedom; Government provided incentives for me to go; Government forced me to move; Other

Of all the reasons you mentioned, could you please rank the top three most important factors?

[Write number of code from above reason in first, second and third place below, with number 1 as the most important]

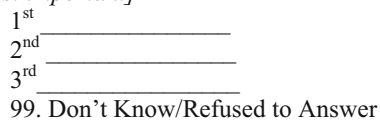

Up until now, have members of your household left temporarily or permanently for other places or even abroad? (Non-migrant) -Up until now, have other members of your household in your previous location left temporarily or permanently for other places, or even abroad?

[Excluding respondent](Migrant)

1. Yes

2. No

99. Don't Know/Refused to Answer

Do you know of anyone who left after having experienced the same event(s) (drought/desertification/flood/cyclone/etc)? [Not from the same HH] (Non-migrant) - Do you know anyone else who left from your previous location around the same time you did? [Other than you] (Migrant)

1. Yes

2. No

99. Don't Know/Refused to Answer

Where did they go? [List all locations mentioned]

Would you be willing to provide us with the name and contact information for these people so that we may ask a similar set of questions? 


\section{References}

Adamo, S., \& Izazola, H. (2010). Human migration and the environment. Population and Environment, 32(2-3), 105-108.

Adams, H., \& Adger, W. N. (2013). The contribution of ecosystem services to place utility as a determinant of migration decision-making. Environmental Research Letters, 8(1), 1-6.

Adger, W. N., Arnell, N. W., Black, R., Dercon, S., Geddes, A., \& Thomas, D. S. G. (2015). Focus on environmental risks and migration: Causes and consequences. Environmental Research Letters, $10(1), 060201$.

Adger, N. W., Lorenzoni, I., \& O’Brien, K. (Eds.). (2009). Adapting to climate change: Thresholds, values, governance. Cambridge: Cambridge University Press.

Bardsley, D. K., \& Hugo, G. J. (2010). Migration and climate change: Examining thresholds of change to guide effective adaptation decision-making. Population and Environment, 32(2), 238-262.

Barrios, S., Bertinelli, L., \& Strobl, E. (2010). Trends in rainfall and economic growth in Africa: A neglected cause of the African growth tragedy. Review of Economics and Statistics, 92(2), 350-366.

Beegle, K., De Weerdt, J., \& Dercon, S. (2011). Migration and economic mobility in Tanzania: Evidence from a tracking survey. Review of Economics and Statistics, 93(3), 1010-1033.

Beine, M., Docquier, F., \& Rapoport, H. (2008). Brain drain and human capital formation in developing countries: Winners and losers. Economic Journal, 118(528), 631-652.

Beine, M., \& Parsons, C. (2015). Climatic factors as determinants of international migration. Scandinavian Journal of Economics, 117(2), 723-767.

Below, T. B., Mutabazi, K. D., Kirschke, D., Franke, C., Sieber, S., Siebert, R., \& Tscherning, K. (2012). Can farmers' adaptation to climate change be explained by socio-economic Household-level variables? Global Environmental Change, 22(1), 223-235.

Bernauer, T., Böhmelt, T., \& Koubi, V. (2012). Environmental changes and violent conflict. Environmental Research Letters, 7(1), 1-8.

Black, R., Adger, W. N., Arnell, N. W., Dercon, S., Geddes, A., \& Thomas, D. S. G. (2011a). The effect of environmental change on human migration. Global Environmental Change, 21(S1), S3-S11.

Black, R., Arnell, N. W., Adger, W. N., Thomas, D., \& Geddes, A. (2013). Migration, immobility, and displacement outcomes of extreme events in nature and society. Environmental Science \& Policy, 27(1), S32-S43.

Black, R., Bennett, S. R. G., Thomas, S. M., \& Beddington, J. R. (2011b). Climate change: Migration as adaptation. Nature, 478(7370), 477-479.

Black, R., \& Collyer, M. (2014). Populations 'trapped' at times of crisis. Forced Migration Review, 45, 52-56.

Black, R., Kniveton, D., \& Schmidt-Verkerk, K. (2011c). Migration and climate change: Towards an integrated assessment of sensitivity. Environment and Planning A, 43(2), 431-450.

Bohra-Mishraa, P., Oppenheimera, M., \& Hsiang, S. M. (2014). Nonlinear permanent migration response to climatic variations but minimal response to disasters. Proceeding of National Academy of Science, 111(27), 9780-9785.

Bryan, E., Ringler, C., Okoba, B., Roncoli, C., Silvestri, S., \& Herrero, M. (2013). Adapting agriculture to climate change in Kenya: Household strategies and determinants. Journal of Environmental Management, 114(15), 26-35.

Bueno de Mesquita, B., Smith, A., Siverson, R. M., \& Morrow, J. D. (2003). The logic of political survival. Cambridge, MA: MIT Press.

Burke, M., \& Emerick. K. (forthcoming). Adaptation to climate change: Evidence from US agriculture. American Economic Journal -Economic Policy.

CEEPA. (2008). Climate change and agriculture in Africa. London: Earthscan, Centre for Environmental Economics and Policy in Africa.

Chinvanno, S., Souvannalath, S., Lersupavithnapa, B., Kerdsuk, V., \& Nguyen, T. T. H. (2008). Strategies for managing climate risks in the Lower Mekong River Basin: A pace based approach. In N. Leary, J. Adejuwon, V. Barros, I. Burton, J. Kulkarni, \& R. Lasco (Eds.), Climate change and adaptation (pp. 228-246). London: Earthscan.

Clarke, K. (2005). The phantom menace: Omitted variable bias in econometric research. Conflict Management and Peace Science, 22(4), 341-352.

Clarke, K. (2009). Return of the phantom menace: omitted variable bias in political research. Conflict Management and Peace Science, 26(1), 46-66. 
Dell, M., Jones, B., \& Olken, B. (2014). What do we learn from the weather? The new climate-economy literature. Journal of Economic Literature, 52(3), 740-798.

Dessai, S., Adger, W. N., Hulme, M., Turnpenny, J., Köhler, J., \& Warren, R. (2004). Defining and experiencing dangerous climate change: An editorial essay. Climatic Change, 64, 11-25.

Devine-Wright, P. (2013). Think global, act local? The relevance of place attachments and place identities in a climate changed world. Global Environmental Change, 23(1), 61-69.

Di Falco, S., \& Veronesi, M. (2013). How can African agriculture adapt to climate change? A counterfactual analysis from Ethiopia. Land Economics, 89(4), 743-766.

Dillon, A., Mueller, V., \& Salau, S. (2011). Migratory responses to agricultural risk in Northern Nigeria. American Journal of Agricultural Economics, 93(4), 1048-1061.

Docquier, F., Lohest, O., \& Marfouk, A. (2007). Brain drain in developing countries. World Bank Economic Review, 21(2), 193-218.

Doevenspeck, M. (2011). The thin line between choice and flight: Environment and migration in rural Benin. International Migration, 49(S1), e50-e68.

Dun, O., \& Gemenne, F. (2008). Defining environmental migration. Forced Migration Review, 31(1), $10-11$.

EACH-FOR (Environmental Change and Forced Migration Scenarios). http://www.each-for.eu Economic Review, 75(1), 173-178.

EM-DAT: The OFDA/CRED International Disaster Database. Université Catholique de Louvain, Brussels (Belgium), www.emdat.be.

Feng, S., Krueger, A. B., \& Oppenheimer, M. (2010). Linkages among climate change, crop yields and Mexico-US cross-border migration. Proceeding of National Academy of Science, 107(32), $14257-14262$.

Ferrer-i-Carbonell, A., \& Gowdy, J. M. (2007). Environmental degradation and happiness. Ecological Economics, 60(3), 509-516.

Foresight Migration and Global Environmental Change. (2011) Final project report. London: The Government Office for Science. http://www.bis.gov.uk/foresight/ migration.

Fussell, E., Sastry, N., \& Van Landingham, M. (2010). Race, socioeconomic status, and return migration to New Orleans after Hurricane Katrina. Population and Environment, 31(1-3), 20-42.

Gelman, A., \& Hill, J. (2007). Data analysis using regression and multilevel/hierarchical models. Cambridge: Cambridge University Press.

Gemenne, F. (2011). Why the numbers don't add up: A review of estimates and predictions of people displaced by environmental changes. Global Environmental Change, 21(S1), S41-S49.

Gourdji, S., Läderach, P., Valle, A. M., Martinez, C. Z., \& Lobell, D. B. (2015). Historical climate trends, deforestation, and maize and bean yields in Nicaragua. Agricultural and Forest Meteorology, 200, 270-281.

Gray, C. L. (2009). Environment, land, and rural out-migration in the Southern Ecuadorian Andes. World Development, 37(2), 457-468.

Gray, C. L. (2011). Soil quality and human migration in Kenya and Uganda. Global Environmental Change, 21(2), 421-430.

Gray, C., \& Bilsborrow, R. (2013). Environmental Influences on human migration in rural Ecuador. Demography, 50(4), 217-1241.

Gray, C., \& Mueller, V. (2012a). Natural disasters and population mobility in Bangladesh. Proceedings of the National Academy of Sciences, 109(16), 6000-6005.

Gray, C., \& Mueller, V. (2012b). Droughts and population mobility in rural Ethiopia. World Development, 40(1), 134-145.

Grothmann, T., \& Patt, A. (2005). Adaptive capacity and human cognition: The process of individual adaptation to climate change. Global Environmental Change, 15(3), 199-213.

Halliday, T. (2006). Migration, risk, and liquidity constrains in El Salvador. Economic Development and Cultural Change, 54(4), 893-925.

Harris, J. R., \& Todaro, M. P. (1970). Migration, unemployment, and development: A two-sector analysis. American Economic Review, 60(1), 126-142.

Henry, S., Schoumaker, B., \& Beauchemin, C. (2004). The impact of rainfall on the first out-migration: A multi-level event-history analysis in Burkina Faso. Population and Environment, 5(5), 423-460.

Hunter, L. M. (2005). Migration and environmental hazards. Population and Environment, 26(4), 273-302.

Hunter, L. M., Luna, J. K., \& Norton, R. M. (2015). Environmental dimensions of migration. Annual Review of Sociology, 41(6), 1-21. 
IPCC Fifth Assessment Report (AR5). (2014). Climate change 2014: synthesis report. http://ar5-syr.ipcc. ch/ipcc/ipcc/resources/pdf/IPCC_SynthesisReport.pdf.

Jäger, J., Frühmann, J, Grünberger, S., \& Vag, A. (2009). Environmental change and forced migration scenarios project synthesis report. http://www.each-for.eu/documents/EACH-FOR_Synthesis_ Report_090515.pdf.

Kalnay, E., Kanamitsu, M., Kistler, R., et al. (1996). The NCEP/NCAR 40-year Reanalysis Project. Bulletin of the American Meteorological Society, 77(3), 437-471.

Kandel, W., \& Massey, D. S. (2002). The culture of Mexican migration: A theory and empirical analysis. Social Forces, 80(3), 981-1004.

Kelley, C. P., Mohtadi, S., Cane, M. A., Seager, R., \& Kushnir, Y. (2015). Climate change in the fertile crescent and implications of the recent Syrian drought. Proceedings of the National Academy of Sciences, 112(11), 3241-3246.

Knapp, T. A., \& Graves, P. E. (1989). On the role of amenities in models of migration and regional development. Journal of Regional Science, 29(1), 71-87.

Kniveton, D., Schmidt-Verkerk, K., Smith, C., \& Black, R. (2008). Climate change and migration: Improving methodologies to estimate flows. Migration Research Series No. 33. Geneva: International Organization for Migration.

Kreft, S., \& Eckstein, D. (2014). Global Climate Risk Index 2014. Who suffers most from extreme weather events? Weather-related loss events in 2012 and 1993 to 2012. Briefing Paper, Germanwatch, Bonn.

Laczko, F., \& Aghazarm, C. (Eds.). (2009). Migration, environment, and climate change: Assessing the evidence. Geneva: International Organization for Migration.

Landis, S. (2014). Temperature seasonality and violent conflict: The inconsistencies of a warming planet. Journal of Peace Research, 51(5), 603-618.

Lewicka, M. (2011). On the variety of people's relationship with places. Environment and Behavior, 43(5), 676-709.

Lilleør, H. B., \& Van den Broeck, K. (2011). Drivers of Migration and Climate Change in LDCs. Global Environmental Change, 21(S1), S70-S81.

Luechinger, S., \& Raschky, P. A. (2009). Valuing flood disasters using the life satisfaction approach. Journal of Public Economics, 93(3-4), 620-633.

Maddison, D., \& Rehdanz, K. (2011). The impact of climate on life-satisfaction. Ecological Economics, 70(12), 2437-2445.

Marchiori, L., Maystadt, J., \& Schumacher, I. (2012). The impact of weather anomalies on migration in Sub-Saharan Africa. Journal of Environmental Economics and Management, 63(3), 355-374.

Marshall M., Gurr, T., \& Jaggers, K. (2013). Polity IV project: Political regime characteristics and transitions, 1800-2013. http://www.systemicpeace.org/inscrdata.html.

Massey, D. S. (1990a). The social and economic origins of immigration. Annals of the American Academy of Political and Social Science, 510(1), 60-72.

Massey, D. S. (1990b). Social structure, household strategies, and the cumulative causation of migration. Population Index, 56(1), 3-26.

Massey, D. S., Axinn, W., \& Ghimire, D. (2010). Environmental change and out-migration: Evidence from Nepal. Population and Environment, 32(1), 109-136.

McLeman, R. (2006). Migration out of 1930s rural Eastern Oklahoma: Insights for climate change research. Great Plains Quarterly, 26(1), 27-40.

McLeman, R. (2014). Climate and human migration: Past, experiences. Future Challenges: Cambridge University Press.

Mortreux, C., \& Barnett, J. (2009). Climate change, migration, and adaptation in Funafuti, Tuvalu. Global Environmental Change, 19(1), 105-112.

Most, B. A., \& Starr, H. (1989). Inquiry, logic and international politics. Columbia, SC: University of South Carolina Press.

Mueller, V., Gray, C., \& Kosec, K. (2014). Heat stress increases long-term human migration in rural Pakistan. Nature Climate Change, 4, 182-185.

Myers, C. A., Slack, T., \& Singelmann, J. (2008). Social vulnerability and migration in the wake of disaster: The case of Hurricanes Katrina and Rita. Population and Environment, 29(6), 271-291.

ND-GAIN (Notre Dame Global Adaptation Index). (2013). Climate Change Adaptation Program. University of Notre Dame's Environmental Change initiative (ND-ECI). http://index.gain.org/ ranking.

Obokata, R., Veronis, L., \& McLeman, R. (2014). Empirical research on international environmental migration: A systemic review. Population and Environment, 36(1), 111-135. 
Oster, E. (2015). Unobservable selection and coefficient stability: Theory and evidence. NBER Working Paper, Brown University.

Paul, B. K. (2005). Evidence against disaster-induced migration: The 2004 Tornado in North-Central Bangladesh. Disasters, 29(4), 370-385.

Paul, S. K., \& Routray, J. K. (2010). Flood proneness and coping strategies: The experiences of two villages in Bangladesh. Disasters, 34(2), 498-508.

Penning-Rowsell, E., Sultana, P., \& Thompson, P. M. (2013). The 'Last Resort'? Population movement in response to climate-related hazards in Bangladesh. Environmental Science \& Policy, 27((Suppl)), s44-s59.

Piguet, E. (2010). Linking climate change, environmental degradation, and migration: A Methodological overview. Wiley Interdisciplinary Reviews: Climate Change, 1(4), 517-524.

Piguet, E., Pécoud, A., \& de Guchteneire, P. (2011). Migration and climate change. Cambridge: Cambridge University Press.

Rabe-Hesketh, S., \& Skrondal, A. (2009). Multilevel and longitudinal modeling using Stata. College Station, TX: Stata Press.

Raleigh, C. A. (2011). The search for safety: The effects of conflict, poverty and ecological influences on migration in the developing world. Global Environmental Change, 21(S1), S82-S93.

Raleigh, C., Jordan, L., \& Salehyan, I. (2008). Assessing the impact of climate change on migration and conflict. Paper prepared for the social dimensions of climate change, World Bank.

Renaud, F. G., Dun, O., Warner, C., \& Bogardi, J. (2011). A Decision framework for environmentally induced migration. International Migration, 49(1), e3-e29.

Reuveny, R. (2007). Climate change-induced migration and violent conflict. Political Geography, 26(6), 656-673.

Reuveny, R., \& Moore, W. H. (2009). Does environmental degradation influence migration? Emigration to developed countries in the late 1980s and 1990s. Social Science Quarterly, 90(3), 461-479.

Robalino, J., Jimenez, J., \& Chacón, A. (2015). The effect of hydro-meteorological emergencies on internal migration. World Development, 67(3), 438-448.

Saldaña-Zorrilla, S. O., \& Sandberg, K. (2009). Impact of climate-related disasters on human migration in Mexico: a spatial model. Climatic Change, 96, 97-118.

Salehyan, I., \& Gleditsch, K. S. (2006). Refugee flows and the spread of civil war. International Organization, 60(2), 335-366.

Seo, S. N., McCarl, B. A., McCarl, B. A., \& Mendelsohn, R. (2010). From beef cattle to sheep under global warming? An analysis of adaptation by livestock species choice in South America. Ecological Economics, 69(12), 2486-2494.

Speare, A. (1974). Residential satisfaction as an intervening variable in residential mobility. Demography, 11(2), 173-188.

Stark, O., \& Bloom, D. E. (1985). The new economics of labor migration. American Economic Review, 75(1), 173-178.

Stark, O., \& Levhari, D. (1982). On migration and risk in LDCs. Economic Development and Cultural Change, 31(1), 191-196.

Stark, O., \& Lucas, R. E. B. (1988). Migration, remittances, and the family. Economic Development and Cultural Change, 36(3), 465-481.

Todaro, M. P. (1969). A model of labor migration and urban unemployment in less developed countries. American Economic Review, 59(1), 138-148.

Van Der Land, V., \& Hummel, D. (2013). Vulnerability and the role of education in environmentally induced migration in Mali and Senegal. Ecology and Society, 18(4), 14. doi:10.5751/ES-05830180414.

Warner, C. (2011). Environmental change and migration: Methodological considerations from groundbreaking global survey. Population and Environment, 33(1), 3-27.

Wolpert, J. (1966). Migration as an adjustment to environmental stress. Journal of Social Issues, 22(4), 92-102.

World Bank. (2013). Climate risk and adaptation country profiles. http://sdwebx.worldbank.org/ climateportalb/home.cfm?page $=$ country_profile $\&$ CCode $=\&$ ThisTab $=$ Overview . 